\title{
THE DISTRIBUTION OF PRODUCER GAS AS A MEANS OF ALLEVIATING THE SMOKE NUISANCE.
}

By A. S. E. ACKERMANN, B.Sc.Lond., A.C.G.I., A.Mr.Tnst.C.E.

(MEMBER.)

\begin{abstract}
NY scheme for alleviating, if not entirely removing, the smoke nuisance A must necessarily be very costly in the case of London, on account of its vast size. For example, eren so small a cost as one shilling per house amounts to $£ 30,000$, as there are some 600,000 houses in London, and this would go but a very little way towards the cost of a scheme, which, to be a complete success, must ultimately deal with every house, for in London the domestic forms 70 per cent. of the total smoke, ${ }^{*}$ though one frequently hears it said that the former is of little account. We must not forget, howerer, what an extremely costly thing fog is to London, and how farreaching are its evil effects. The Hon. Rollo Russell has estimated the total cost of fogs in London as wer $\mathcal{E} .5,000,000$ per ammum. $\dagger$ As even one year's cost would provide capital enough for a very lirge scheme, I argue that a successful (even if very costly) scheme would pay.

Dr. W. N. Shaw, in his paper just quoted, gives the following averages during the twenty years, 1881 to 1900 :-
\end{abstract}

\section{London :-}

$$
\text { Percentage of possible duration of sunshine. }
$$

Jan. Feb. Mar. Apr. May June July Aug. Sept. Oct. Nov. Dec.

$\begin{array}{llllllllllll}10 & 15 & 23 & 31 & 38 & 36 & 38 & 39 & 34 & 24 & 14 & !\end{array}$

Average for the Southern District of England :-

$\begin{array}{llllllllllll}21 & 28 & 38 & 42 & 413 & 43 & 46 & 47 & 44 & 37 & 24 & 21\end{array}$

In Nov., Dec., Jan., and Feb. London gets only half the sunshine that Southern England gets, or only about 12 per cent. of the possible amount.

* Dr. W. N. Shaw, R. San. Inst. Congress at Manchester, 190:.

+ "Smoke in relation to Fogs in London," The Smoke Abatement Society. 
During May to August, when less house coal is burnt, London sunshine amounts to 84 per cent. of that in Southern England, or $37 \cdot 8$ per cent. of the possible. This shows a loss, clue to the excess of winter smoke over summer smoke, of $3 \pm$ per cent.

My proposal is that producer gas should be distributed to houses for warming and cooking and to factories for industrial purposes. This gas is made from the cheapest coil at a cost of $3 \frac{1}{2} \mathrm{l}$. per $1,000 \mathrm{c}$. ft., and has a calorific value of about one quarter that of ordinary illuminating gas. 1s. 2d. worth of producer gas is equivalent to $1,000 \mathrm{c}$. $\mathrm{ft}$. of ordinary gas ensting 3s. The South Staffordshire Mond Gas Co. (cap. $£ 1,000,000$ ), having power over 123 square miles, now have some 14 miles of producer gas mains laid, and though they started to deliver gas only six months ago, the output is already 12 million $c$. ft. per day from the generating station at Dudley Port. This gas, however, is all used for industrial purposes, so will not decrease domestic smoke. The Act of Parliament under which the Company was formed does not allow them to distribute gas "for use in private dwelling houses." The price raries from 2 d. to 4 d. per 1,000 c. ft., or say 1s. for the heat equivalent of $1,000 \mathrm{c}$. $\mathrm{ft}$. of orlinary gas, which in South Staffordshire costs 2 s. 5d. per 1,000 c. ft. The minimum quantity which the Company may supply to any one customer is one million c. ft. per yaur, and the miximum price they may charge is tol. per $1,000 \mathrm{c.}$ ft.

Producer gas is suitable for practically all purposes for which ordinary gas can be used, except that it will not dn for illuminating, as its flame is non-luminous and its calorific value is too low for it to be used with a mantle. The only objection that has been raised against it is that it contains about 20 per cent. of the very poisonous carbonic monoxile, but it is easy to rerluce this amount. The South Staffordshire Co.'s Act does not allow more than 14 per cent. (and the gas has to have "a distinct, readily perceptible smell"), while ordinary illuminating gas, which is of ten enriched with water-gas, sometimes contains 12 per cent. of $\mathrm{CO}$, so that the difference on that point is very small.

When I first suggested the distribution of producer gas for the purposes named some three years ago, I was nut aware that it had been used for cooking and warming, though of course nitural gas (which has a much higher calorific value) las been so distributed and used in America for years with signal success. I learned that the Gloucested County Asylum has used producer gas for cooking during the last twenty-two years; and that the Walthamstow Isolation Hospital has used it during the last five years for driving gas-engines, for warming the blocks of builclings, the hot 
water supply, and for the whole of the cooking. The latter in December, 1903 , was for 80 per'sons, but the same plant could easily serve 200 . The cooking apparatus is arranged against two of the walls, and over it there are two wrought iron hoods which stand out $4 \mathrm{ft}$. $6 \mathrm{in}$. from the walls, and are placed $6 \mathrm{ft}$. above the floor-level. One of these was provided with an electric fan for drawing off the fumes, but very of ten it was found not necessary to use this. There was a slight smell of burning sulphur on entering the kitchen, and but for this it would have been impossible to tell that anything but ordinary gas was in use. The whole of the plant had, when I inspected it, been in use for two years and eiglit months. There had been no renewals, and they had had no trouble whatever. No hearlaches, no accidents. The stoves, etc., appeared exactly the same as any ordinary gas-stoves, except that the jets were slightly larger.

Producer gas is also used for cooking at the works of the following firms :-Messrs. Ashmore, Benson, Peise \& Co., Ltd., Strckton-on-Tees; Messrs. Brunner, Mond \& Co., Ltd., Wimington; and The Co-operative Wholesale Society, Irlam.

One very important point, as it woulı greatly reduce the cost of introducing producer gas warming, is that the existing open fire grates could be used without alteration, simply by the addition of a multiple Bunsen burner and hollow asbestos balls such as are used in gas-stoves using ordinary was. This would not be the most economical way of using the gas, but would probably be sufficiently so in the case of most existing grates, while new houses could be fitterl with efficient gras-stoves. In either case we should have the advantage (sinitary and sentimental) of an open fire, and it is hardly necessary to point ont that properly clesigned and fitted gas-stoves are quite as wholesome as coul-fires. Unfortunately, there are many gas-stores on the market which are poorly designed and far from efficient, and which when fixed either bave no chimney at all, or a very unsatisfactory one. It is such stoves and statements which gave gas a bad name for warming some years ago and have done much harm by retarding its use, though it must lue admitted that with gas at $3 \mathrm{~s}$. per 1,000 cubic feet, the cost is too much where constant fires are wanted.

The advantages of gas warming and cuoking as compared with coal are:-1. Greater convenience. 2. Cleanliness. 3. Labour saring. 4. Economy (especially if producer gas be used).

Under these four headings we have:--

1. The fire is started in a moment and very soon reaches its maximum temperature, whereas a coal-fire takes vory much longer to do this. 
2. When done with, the fire can be put out at once, so that there is no waste of fuel in the fire "burning itself out."

3. There is no heavy and dirty coal to be handled.

4. There are 110 ashes and cinclers to be removed, the removal of which causes much dust in the room.

5. There are no grates to clean, except very occasionally.

Items 3,4, and 5 are very important to the housewife, especially when she is without a servant.

6. The temperature can be regulater to a nicety.

7. There is less danger of fire.

8 . No space is required for the storage of coal, either in the cellar, or in the rooms in which the fires are wanted.

9. The quantity of gas used is rery conveniently measured by a meter, and can be easily checked by the user, whereas not one householder in a thousand checks the weight of coal supplied to him, because of the time and difficulty of so doing.

10. Gas cannot be stolen as easily as coal.

11. Lastly, and certainly not the least advantage, especially in the eyes of such a meeting as this, there is no smoke!

As to whether the central station for generating the gas should be in the town or close to the coalficlds would depend on circumstances. There are certainly very many alvantages in having the station by the coalfields, as it would save a great amount of the costly handling and freight of the coal, and the difference in the cost of the dearer site for the station in the town.

It has been objected that the rolume of gas would be so great that the mains would have to be excessively large. Fortunately gas is compressible. The pressure at which ordinary gas is distributed is equal to about 3 inches of water, which is equal to $0.108 \mathrm{lb}$. per square inch (above atmospheric pressure), while in America they are distributing gas at a pressure of 20 , and even $80 \mathrm{lb}$. per square inch (above atmospheric pressure). The volume of a gas is inversely proportional to its absolute pressure, so that in increasing the pressure from $0.108 \mathrm{lb}$. to $20 \mathrm{lb}$. per sq. in. (both by gauge) the volume is reduced to one-half, and if the final pressure be $80 \mathrm{lb}$. per square inch, then the final volume is less than one-siath that of the initial.

Another bugey is that the leakage would be great. This is not found to be so in prictice. Professor F. W. Burstall stated in evideuce before the recent Royal Commission on Coal Supplies that the leakage from the 
84 Producer Gas a Means of alleviating the Smoke Nivisance.

Paris air-mains (in which the pressure is $100 \mathrm{lb}$. per square inch) is only 0.4 per cent. per mile, and that the efficiency of transmission is considerably better than in the case of electricity! In addition to this we have had many years of experience of the distribution of ordinary gas.

The Hon. Rollo Russell has proposed that a tax should be put on all houses producing much smoke, in the same way that factory owners are now fined. If the money so collected were used for the produrer gas scheme, people would be provided with the means of aroiding the making of smoke and thus of avoiding the tax, while those indifferent to the interests of the community would rightly have to pay. New Iork has long since taken the far more drastic step of prohibiting the use of any but anthracite (smokeless) coal, and is rewarled with a practically smokeless city. 